\title{
Public Participation Model in The Juvenile Criminal Justice System in Indonesia
}

\author{
Pujiyono $^{1}$, Nur Rochaeti ${ }^{2}$, Lita Tyesta ALW ${ }^{3}$ \\ \{pujifhundip@yahoo.com ${ }^{1}$, iyenk283@yahoo.co.id ${ }^{2}$, litatyestalita@yahoo.com ${ }^{3}$ \} \\ 1,2,3Faculty of Law, Diponegoro University, Semarang, Indonesia
}

\begin{abstract}
Diversion mechanism and restorative justice are inherent in the juvenile justice system in an effort of the protection to children in conflict with the law. Restorative approaches have long been practiced in the resolution of a criminal case (child) in Indonesia without involving the agents of the State. The study aimed to uncover and discover the practices of public participation and to build a model of public participation in the juvenile criminal justice system so that children are prevented from judicial formalism process that has negative impacts. The research results show that restorative case resolution model is part of the value of public togetherness and responsibility against criminal acts (especially children) as a manifestation of public failure in educating the offenders. The resolution by promoting deliberation, repairing the damage, fostering a sense of guilt and sense of responsibility of the offenders and the community are the parts of life, which are instinctively used in any resolution of criminal cases. Such practices have no place in the judicial process; thus, when a case has been resolved in a community by positive law, the judicial process is still conducted. The integrative model enables a public resolution to be an integral part of the implementation of the juvenile justice system as a form of out of court settlement which has legal certainty and power.
\end{abstract}

Keyword:public participation model, the juvenile criminal justice system

\section{Introduction}

People are expected to participate and be involved in a child criminal case through Diversion and Restorative Justice. Under Section 28, I of the Constitution of 1945, i.e., in (3), the cultural identities and rights of traditional communities are respected in line with the times and civilization. This means that any activity in the community about the values of traditional and local knowledge is respected and recognized by the period and civilization.

International instruments and national instruments have arranged that the legal mechanisms and law enforcement officers and citizens are a network that is responsible for the implementation of the juvenile criminal justice system and prefer the informal approach as preventing juvenile against the law.

Children naturally have specific rights which are different from adults as they are vulnerable to violence, abuse, and exploitation. They are going through the growth process of becoming adults, so it is expected that they are responsible for their actions, including in the field of law. Children need particular protection and treatment, particularly against the acts that may harm their future development, because their physical and mental conditions are not stable. Thus, their ability to act and responsibility are not the same as adults. They require different treatment from adults who violate the law. Children need special court with the emphasis on the patterns of the settlement out of court, and litigation is the last resort as an 
effort to prevent children from evil stigma, imprisonment, and mistreatment that seize children's growth.

The protection of juvenile against the law has been set up in several international legal instruments including the UN Standard Minimum Rules on the Administration of Justice for Juvenile ("Beijing Rules") by the United Nations Assembly Resolution No. 43/33 November 29, 1985 and the UN Guidelines order Crime Prevention Centre ("Riyadh Guidelines") authorized and declared in the UN General Assembly Resolution No. 45/112 December 14, 1990 , with the assertion that the UN resolution is the minimum standards for the protection of juvenile from all forms of deprivation of liberty, which is based on human rights, and it prevents the child from the side effects of all forms of detention in order to achieve the integration of children into society. Also, the Convention on the Rights of the Child (Convention on the Rights of the Child) is acting as international law began on 2 September 1990, which saw the need to perform the steps of systematic and comprehensive to protect children who conflict with the law.

The juvenile courts have shown that they mostly focus on sentencing, particularly criminal sentencing. Thus, it does not benefit the children, and it is even considered harmful. Child development becomes impaired, and they will experience depression, trauma, moral degradation, and evil stigma, which eventually deprive their future.

Juvenile offenders (juvenile delinquency) do not appear from the offenders' full awareness considering the lack of physical and psychological immaturity. Juvenile delinquency often occurs because of curiosity, imitation, and even due to environmental influences. The occurrence of juvenile delinquency is the failure of families and communities in educating children so that the responsibilities must not be fully charged to them. The juvenile courts have failed in producing the justice of "three-dimension" in the child, victim, and community. Public and victim participations do not get an authentic maximum space as juvenile justice is a formality.

Indonesia is a country with a wide range of cultural property and the values of local wisdom in varied social order so that a case of juvenile delinquency which injures society's values, we need a process that is also based on the values of local wisdom without involving the legal process in an approach that is based on the principles of decency and fairness in the mechanism mutually agreed. Thus, the process has already existed in reality, but it has no place in our positive law. Hence, the study found an urgency to examine the practices of resolving cases of children through public participation and to find a model that can align (integrate) the formal settlement (litigation) with the settlement in society (non-litigation) to find "three-dimensional" and substantial ( authentic) justice.

\section{Methodology}

The study used the approach of socio-legal research equipped with the legislative, historical, and concept (philosophical) approaches that will be used continuously and interconnected in order to obtain the data to be studied, analyzed, and interpreted so that the problems in the study on public participation can be developed into a model of juvenile justice system in Indonesia. 


\section{Findings.}

\subsection{Protection Policy for Children in Conflict with Law}

Children justice covers all inspection activities and the decision of the cases related to the interests of the child" (Sudarto)[1]. The inspection and decision of child cases should be geared to the protection and best interests of children. Arief Gosita sees child protection as a joint activity aimed at seeking security of providing and meeting the child's spiritual and physical welfare to needs of children in accordance with their interests and human rights based on the concept of parent patriae; the state provides care and protection to children as proper as the parents to their children [2].

The protection policy to the children in conflict with the law is conducted through the adoption of international instruments or national laws. The juvenile justice system (Law No. 11 of 2012) protects the children in conflict with the law through a policy of litigation and non-litigation. Non-litigation policy (with diversion) is the central policy inherent in the examination stage, while the nature of the litigation process is the last resource. Children should be avoided as much as possible from the judicial process to protect the rights of the child. The process of juvenile justice is performed with regard to the principles of protection, justice, non-discrimination, best interests of the child, respect for the views of the child, paying attention to the survival and development of the child, coaching and mentoring, proportional, sentencing, and deprivation of liberty as the last resort and should be avoided from the principle of retaliation. Juvenile justice prefers the settlement of win-win solution in the offender, victim, and community. Therefore, in the implementation, it uses the concept of restorative justice approach.

Although the juvenile criminal justice approach is non-litigation (diversion) and restorative justice, the implementation is stuck in the formalism of judicial process as it is conducted by and attached to each stage of the case examination process. In dealing with the process, law enforcement officers do not entirely give up his position as the law enforcement officers who are repressive when implementing the settlements of non-litigation and nonlitigation and preventing active participation (initiative) of the community.

According to John Braithwaite:

The types of restorative justice standards are articulated: limiting, maximizing, and enabling standards. They are developed as multidimensional criteria for evaluating restorative justice programs. A way of summarizing the long list of standards is that they define ways of securing the republican freedom (dominion) of citizens through repair, transformation, empowerment with others, and limiting the exercise of power over others. A defense of the list is also articulated in terms of values that can be found in consensus UN Human Rights agreements and from what we know empirically about what citizens seek from restorative justice. Ultimately, such a top-down list motivated by UN instruments or the ruminations of intellectuals are only crucial for supplying a provisional and revisable agenda for bottom-up deliberation on restorative justice standards appropriate to distinctively social anxieties about injustice. A method is outlined for moving bottom-up from standards citizens settling for evaluating their local program to aggregating these into national and international standards [3].

This is defined in the mechanism of justice recovery, and the method of governance is the need of citizens also to regulate their local programs for national and international standards.

According to Sidney W.A. Dekker and Hugh Breakey, culture needs to be considered, including in substantive justice that regulates how rules and procedures are fair and legitimate; and restorative justice which aims to restore the status of individuals involved and heal the 
relations and injuries of victims and the broader community after the occurrence of ethical violations, as what is stated in his opinion:

Culture needs to be considered. These include substantive justice which prescribes how regulations, rules, and procedures themselves are fair and legitimate; procedural justice which sets down processes for determining rule-breaches, offers protections for the accused, and governs who should make such determinations; and restorative justice which aims to restore the status of the individual involved and heal relationships and injuries of victims and the broader community in the wake of an ethical breach. Just culture approaches need to provide such foundations for a genuinely just safety culture, to be conducive to reporting, engagement, and safety improvement. [4]

\subsection{Public Role and Participation in Juvenile Criminal Justice System}

Indonesia has the cultural, local wisdom, and socio-philosophical values adopted and inherent in society. As a communal society, Indonesian people always promote harmony, balance, and compatibility together. The settlement of social problems, including legal issues, always puts the family approach with deliberation.

A criminal act is defined as a collective failure (community) in educating its citizens. The occurrence of crimes is also interpreted as the disruption of the balance between the minor world (microcosmos) and the significant world (macro cosmos) in people's life (Murder) [5]. Therefore, the settlement of criminal acts is a shared responsibility. The realization is the settlement of criminal case performed internally that involves people together through traditional institutions and public figures. Such settlement can be seen from the settlement practices of criminal cases (including the case of the child) in the place where the research took place.

In his article, Tyler stated that the goal of this review is to point to common elements shared by this procedural justice approach, the restorative justice movement, and a focus on morality and moral development. Their common goal unites these approaches: to encourage the development or activation of people's internal values so that they will become more motivated to engage in self-regulatory behavior. It is suggested that civil society is most effective when its members buy into commonly held values and follow the rules because they are motivated to do so, rather than because incentives or sanctions motivate them. [6]

According to Llewellyn and Howse (1998):

The main elements of the restorative process involve voluntariness, truth-telling, and faceto-face encounter. Consequently, the process should be entirely voluntary for all participants; the offender needs to accept responsibility for the harm and be willing to openly and honestly discuss the criminal behavior, and the participants should meet in a safe and organized setting to collectively agree on an appropriate method of repairing the harm.[7]

The research was conducted in two regions of Bali (Pagringsingan, Tenganan, and Kesiman villages) and Surakarta. Even though the areas have different custom engagement, they have many appreciations and practices of values of local wisdom. Tenganan, Pagringsingan, Kesiman villages which are still governed by customary law called awig awig. Awig awig in the villages set the fines in the event of delinquency (a crime under national law). The fines given depends on the level of existing violations, or warned verbally, admonished in order not to repeat other more serious mistakes. If the faults are considered severe, they will be fined or disekong (expelled) from the villages. Disekong means that they are not allowed to enter the villages dismissed from the members (residents). Although they are still considered residents, they do not have the rights and are not actively invited to the meeting. Their rights are temporarily not granted, such as the voting rights (giving an 
opinion), the right to protection, and they are not attended when married. All of them depend on the weight of their mistakes, and the length can be around five months or six months. If the deed has criminal nature, it may be in the long term and could even be considered to be dismissed. The other sanction is in the form of kasepekan meaning that the public does not regard their existence. Anyone in the sanctions is not involved in public talk; other residents do not regard their existence. The sanctions are found to be more effective for a communal lifestyle that emphasizes their attachment to social life, both religious and customary. Sanctions are decided upon by a meeting in Banjar attended by the community through customary deliberation (traditional justice). For the settlement of the criminal offense committed by a child, there is a tremendous interest in which it is almost entirely settled by indigenous peoples although there are some cases that have continued to criminal proceedings (SPPA). The continuation of such cases since, informal judicial, the informal settlement (out of SPPA) has no legal certainty; in the sense that it cannot end the criminal proceedings

Surakarta is one of the core Javanese cultures because it is traditionally one of the centers for politic and development of Javanese tradition. Kraton is a symbol of the identity of Surakarta city. The existence of Surakarta and Mangkunegaran Sultanates make Surakarta as the shaft, history, art, and culture that still preserves the palace tradition in everyday life. Local social orders are not free from the touches of palace culture and tradition. Surakarta is also one of the regions in Central Java towards the child-friendly city and has the restorative justice agencies in several villages.

In Javanese culture, there are lofty ideals on the culture of peace. Peace will lead to calm, secure, peaceful atmospheres. The principle, like peace, is not just a social philosophy of Java, but it is an extraordinary inner manifestation. The principle adhered in achieving peace is the concept of harmony. Harmony is a condition in which a social balance is reached (Endraswara) [8]. Harmony occurs because of each person respects, keeps the courtesy, and appreciates each other. The souls of kinship and mutual assistance, as well as the concept of tepa slira, are always put forward in life. The relationship among the members always strives towards peace and tolerance.

The Javanese culture is also appropriate in the settlement under the principle of restorative justice. According to John Braithwaite, Restorative Justice is a process in which all parties involved in a particular offense solve collectively to deal with the result of the violations and implications for the future. Furthermore, John Braithwaite states that Restorative Justice is aimed at restoring harmony or balance because the laws are enforced.[9]

The appreciation against the concepts above raises a caring attitude (participation in settlement of children cases), among the public (through foundations and groups) and the government. The study revealed that the initiative case settled through mediation emerged from the families of both parties, both the victim and the perpetrator. A group of people acted as the mentor or mediator/ facilitator to facilitate a meeting between the parties. The meetings were held 2-3 times. Police officers were not involved. The communities involved are incorporated into the Integrated Service Center (PPT) in the local village. PPT consists of the community leaders who participated in the Child-Friendly Village program. As well as the settlement of the children cases with the settlement involving public participation (settled by people), it did not have the legal force (informal) so that some cases continued to the court despite already being settled by the society. 


\subsection{The Model of Public Participation in the Juvenile Justice System in the Future}

The research results indicate that people actively (voluntarily) played the role and participated in settlement of juvenile crimes through traditional institutions and communities with the members of the community concerned with children and the villages or community groups established by the government. The informal settlement materially settled (finish) the "conflict" in the offender, victim, and community, but, from the viewpoint of the state law (formal), it is not recognized as the settlement of the criminal case. Therefore, many cases were still brought to the courts even if the cases were informally (material) had been settled.

Based on the research results and comparative studies, the idea which then appeared as the public participation in the form informal settlement (out of court settlement) and can be integrated as an integral part of criminal justice process by generating a model of public integrative participation. Therefore, any settlement of criminal cases (child) has legal force.

\section{Conclusion}

Criminal law policy (SPPA) and others have given the space of out of court settlement through the concepts of Diversion and Restorative Justice, but they do not accommodate public participation in juvenile criminal cases directly. The communities of the indigenous community, childcare groups, foundations, villages, or the community groups established by the government have played an active role in resolving the cases of children. The nature of the settlement is informal, so it does not have binding legal force because it is not recognized by positive law (SPPA). Therefore, for the settlement by the public to have legal force, it requires the model of "the Integrative Public Participation" in which the informal settlement are integrated into (a part) formal completion (SPPA), so that it has the binding force for resolving the cases of the children in conflict with the law.

\section{References}

[1] Sudarto, Kapita Selekta Hukum Pidana. Bandung: Alumni, 1981.

[2] G. A, Masalah perlindungan Anak. Jakarta: Akademika Pressindo, 1985.

[3] J. Braithwaite, "Setting Standards For restorative Justice," Br. J. Criminol., vol. 42, no. 3, 2002.

[4] Sidney W.A. Dekker; Hugh Breakey, “Just Culture:' Improving Safety By Achieving Substantive," Proced. Restor. Justice, 2016.

[5] M. N, Kebatinan dan Hidup sehari-hari Orang Jawa. Jakarta: Gramedia Pustaka Utama, 1983.

[6] T. R. Tyler, "Restorative Justice, and Procedural Justice: Dealing with Rule Breaking," J. Soc. Issues, vol. 62, no. 2.

[7] J. Latimer, "The Effectiveness Of Restorative Justice Practices: A Meta-Analysis," Prison J., vol. 85, no. 2, p. 127, 2005.

[8] Endraswara S, Falsafah Hidup Jawa, Menggali Mutiara Kebijakan dari Intisari Filsafat Kejawen. Yogyakarta: Cakrawala, 2012.

[9] J. Braithwaite, Restorative Justice : Assessing an Immodest Theory and a Pessimistic Theory Draft to be summited to Crime and Justice: Review of Research. Chicago: University of Chicago Press. 